American Journal of Applied Sciences 2 (7): 1113-1120, 2005

ISSN 1546-9239

(C) 2005, Science Publications

\title{
Effect of Chemical Admixtures on the Engineering Properties of Tropical Peat Soils
}

\author{
Bujang B.K. Huat, Shukri Maail and Thamer Ahmed Mohamed \\ Department of Civil Engineering, University Putra Malaysia, Serdang, Selangor, Malaysia
}

\begin{abstract}
This research describes a study on the effect of chemical (cement and lime) admixtures on the index and engineering properties (compaction and unconfined strength) of tropical peat soils. The ordinary Portland cement and hydrated lime were used. The amounts cement and lime added to the peat soil sample, as a percentage of the dry soil mass was in the range of 5-15\% and $5-25 \%$, respectively. The results of the study show that the addition of the chemical admixture, cement and lime, can improve the engineering properties of tropical peat soils. The soil liquid limit is found to decrease with an increase in the cement and lime content. The soil maximum dry density is found to increase while the optimum water content is found to decrease with an increase in the cement and lime content. The unconfined compressive strength of the soil is found to increase significantly with increase in cement and lime content, especially after a long curing period. However it is also found that higher organic content of the soil negate the positive effect of the cement and lime in altering (improving) the mechanical properties of the soil. When comparing the performance of the cement and lime as a chemical admixture for the tropical peat soil, the ordinary Portland cement appears to perform better than the hydrated lime.
\end{abstract}

Key words: Index properties, cement, compaction, lime, peat, unconfined, compressive strength

\section{INTRODUCTION}

Peat and organic soil represent the extreme form of soft soil. They are subject to instability such as localized sinking and slope failure and massive primary and long-term settlement when subjected to even moderate load increase ${ }^{[1]}$. Buildings on peat are usually suspended on piles, but the ground around it may still settle, creating a scenario as depicted in Fig. 1. In addition, there is discomfort and difficulty of access to the sites, a tremendous variability in material properties and difficulty in sampling. These materials may also change chemically and biologically with time. For example further humification of the organic constituents would alter the soil mechanical properties such as compressibility, shear strength and hydraulic conductivity. Lowering of ground water may cause shrinking and oxidation of peat leading to humification with consequent increase in permeability and compressibility.

It is therefore understandable that constructions and buildings on these types of soils are often avoided whenever possible. However these soils are found in many countries throughout the world. In the US, peat is found in 42 states, with a total acreage of 30 million hectares. Canada and Russia are the two countries with a large area of peat, 170 and 150 million hectares respectively ${ }^{[2]}$. In case of tropical peat, or tropical peat lands, the total world coverage is about 30 million hectares, two thirds of which are in Southeast Asia (Fig. 2). Malaysia has some 3 million hectares (about 8\%) of the country land area covered with tropical peat. While in Indonesia peat covers about 26 million hectares of the country land area, with almost half of the peat land total is found in Indonesia's Kalimantan. Since the coverage of these soils is quite extensive, utilization of these marginal soils are required in an increasing number of instances in the recent years. Hence suitable Geotechnical design parameters and construction techniques needed to be found for this type of ground condition. It is therefore necessary to expand our knowledge on the engineering or mechanical properties of the peat and organic soils.

Peat actually represents an accumulation of the disintegrated plant remains, which have been preserved under condition of incomplete aeration and high water content. It accumulation wherever the conditions are suitable, that is, in areas with excess rainfall and the ground are poorly drained, irrespective of latitude or altitude. Nonetheless, peat deposits tend to be more common in those regions with comparatively cool wet climate. Physico-chemical and biochemical process cause this organic material to remain in a state of preservation over a long period of time. In other words, waterlogged poorly drained condition, not only favor the growth of a particular type of vegetation but also help preserve the plant remains.

Corresponding Author: Bujang B.K. Huat, Department of Civil Engineering, University Putra Mlaysia, Serdang, Selangor, Selangor, Malaysia 

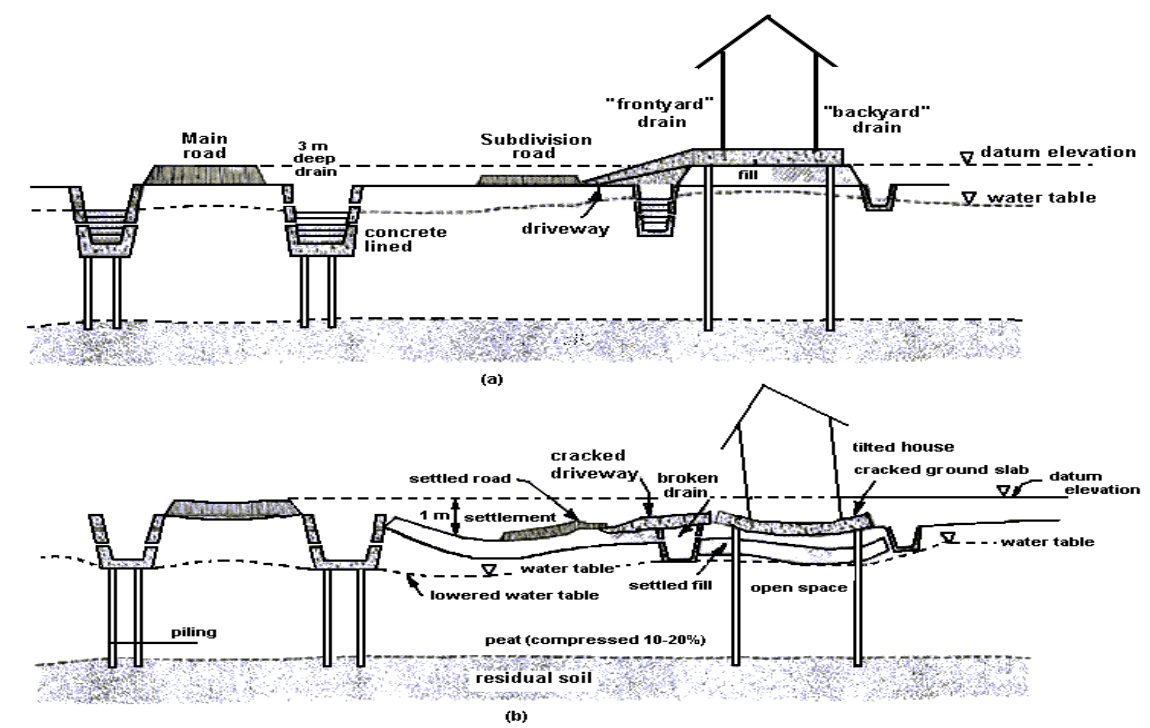

Fig. 1: Typical section of a housing estate on peat (a) Immediately after completion of construction (b) Several years after completion of construction (scale exaggerated)

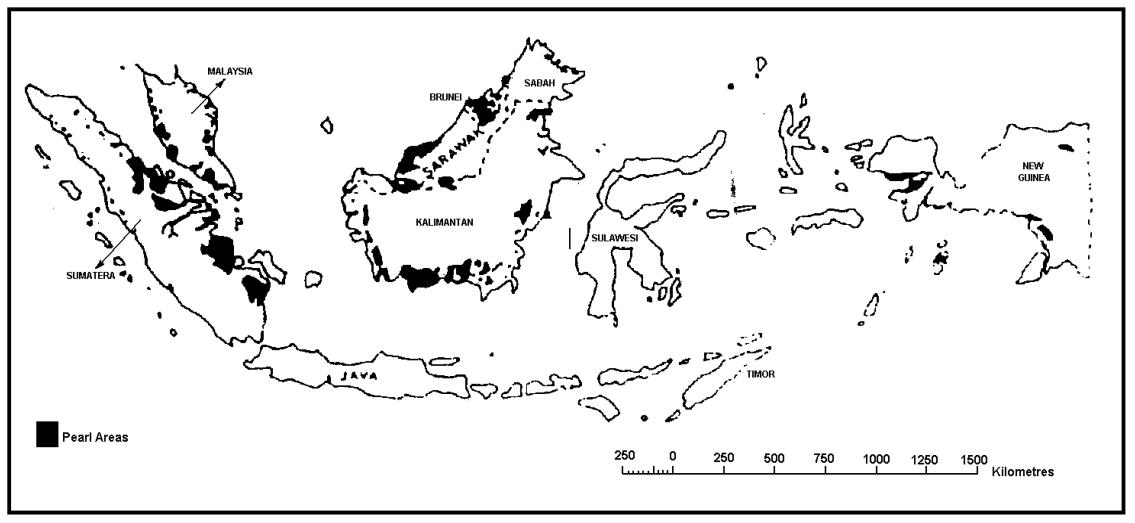

Fig. 2: Tropical peat land of Southeast Asia ${ }^{[3]}$

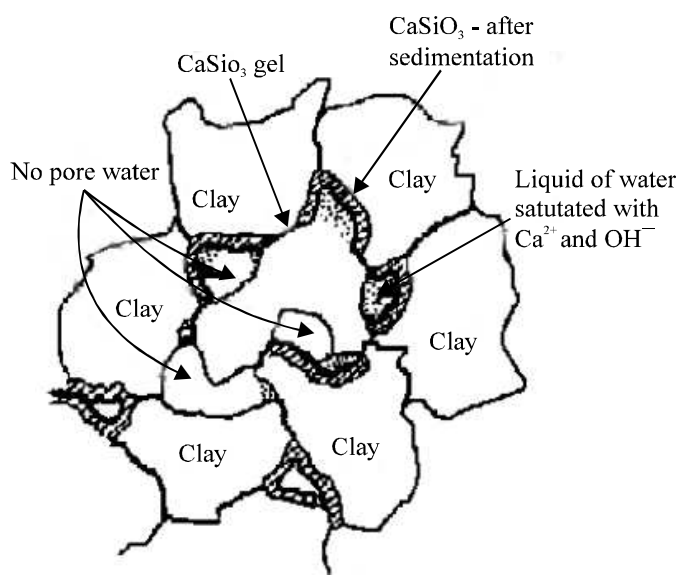

Fig. 3: Principle of soil stability with lime ${ }^{[9]}$

Concerning the formation of the tropical peat, $\mathrm{Lam}^{[4]}$ and Chen et al. ${ }^{[5]}$ postulate the possible event leading to the development of the deposits as results of sea level changes. In terms of thickness, these deposits may vary from just about $1 \mathrm{~m}$ to more than $20 \mathrm{~m}$.

Edii $^{[6]}$ summarizes a number of construction options that can be applied to peat and organic soils, namely: excavation-displacement or replacement; ground improvement and reinforcement to enhance soil strength and stiffness, such as by stage construction and preloading, stone columns, piles, thermal precompression and preload piers; or by reducing driving forces by light-weight fill; and chemical admixture such as cement and lime. These chemical admixtures can be applied either as deep in situ mixing method (limecement columns), or as surface stabilizer.

Chemical admixtures or chemical stabilization always involves treatment of the soil with some kind of chemical compound, which when added to the soil, would result in a chemical reaction. The chemical reaction modifies or enhances the physical and engineering properties of a soil, such as, volume stability and strength. In case of sediment soil such as 
inorganic clay and sand, chemical admixtures such as Portland cement, lime and fly ash are often used.

In case of sediment soils, addition of inorganic chemical stabilizers like cement and lime has two fold effect on the soil-acceleration of flocculation and promotion of chemical bonding. Due to flocculation, the clay particles are electrically attracted and aggregated with each other. This results in an increase in the effective size of the clay aggregation. Such aggregation converts clay into the mechanical equivalent of fine silt. Also, a strong chemical bonding force develops between the individual particles in such aggregation. The chemical bonding depends upon the type of stabilizer employed. Strengths of silt and clay can be improved up to 30 fold $^{[7]}$. However in the case of tropical peat, little is known about it respond to chemical admixtures such as cement and lime.

Cement is used as a soil stabilizing agent especially for road construction, such as for sub base, airport runways and earth dams. It is also used for the construction of low cost houses, especially in the arid region. This material can be used to stabilize sandy and clayey soils. In sediment soils, cement has the effect to reduce the liquid limit and increase the plasticity index and hence increase the workability of soil.

There are a number of factors that influence the soil cement mixture. Among them are:

- Type and properties of soil.

- Quantity and type of cement.

- Soil moisture content.

- Mixing and compaction method.

- Condition and curing time.

In theory any soil can be stabilized with cement. But the increase in the silt and clay content require more cement to be added. Soils most suitable to be stabilized with cement are a mixture of sand and gravel of better grade and with less than $10 \%$ fines passing 75 $\mu \mathrm{m}$ sieve and with coefficient of uniformity of not less than 5. Clayey soil may also be stabilized with cement. Any type of cement can be used to stabilize soil, but the most commonly used is the ordinary Portland cement. For sediment soil, the amount of cement normally used range from 6 to $14 \%$. The presence of organic and sulphate materials in the soil is generally believed to may prevent the cement from hardening. Mechanisms of organic matter interference in strength gain are not completely understood but are thought to include the following (Janz and Johansson ${ }^{[7]}$ ):

- Organic matter can alter the composition and structure of Calcium Silica Hydrate $(\mathrm{C}-\mathrm{S}-\mathrm{H})$ gel, a cementing compound that forms bonds between particles and also type and amount of other hydration products, e.g., ettringite.
- Organic matter holds 10 or more times its dry weight in water and may limit water available for hydration.

- Organic matter forms complexes with aluminosilicates and metal ions interfering with hydration.

Lime is another chemical admixture that is commonly used for stabilizing soil. Lime is produced by the calculations of limestone or dolomite at high temperature (about $900{ }^{\circ} \mathrm{C}$ ). Types of lime available are:

- Hydrated lime $\left(\mathrm{Ca}(\mathrm{OH})_{2}\right)$.

- $\quad$ Quicklime $(\mathrm{CaO})$.

- Mono dehydrated dolomite lime (CA (OH) ${ }_{2}$. MgO).

- Dolomite quick lime.

Lime has actually been used as a soil-stabilizing agent since Roman time ${ }^{[8]}$. In case of sediment soil such as inorganic clay, the amount of lime normally used ranges in between 5 to $10 \%$. Quicklime is more efficient to effect change in soil strength compared with hydrated lime but quick lime is quite dangerous as it can destroy live tissues. When a line is added to soil, a number of chemical reactions will take place. The reactions are:

- Exchange of cation,

- Flocculation and aggregation and

- Pozzolanic.

In sediment soil, the cations exchange reaction and flocculation-aggregation result in changes of clay texture, whereby the clay platelets will combine to form larger particles as shown in Fig. 3. Due to this reaction, the liquid limit of the soil will be reduced while the plastic limit will be increased. As a result, soil plasticity index will be reduced and shrinkage limit will be increased. Therefore the workability of the soil will be enhanced and the soil strength, engineering and deformation properties will be improved. The pozzolanic reaction between soil and lime involve the reaction between lime with the soil silica and alumina to form a cementing material ${ }^{[10]}$. This pozzolanic reaction may continue over a long period of time. High temperature however speeds up the strength increase of a lime soil mixture.

As for the cement, little is known about the peat responses to lime. But the general consensus is that in the peat, the strength gain may not be that high ${ }^{[11]}$. It is generally believed that high water content and low strength of peat's require significant strength gain, which is inhibited by the organic matter. However studies carried out by Arman and Munfakh ${ }^{[12]}$ on the effect of lime stabilization of organic soil from Louisiana showed that the presence of the organic matter does not significantly inhibit the pozzolanic reaction. 
In this study, the results of a study on the effect of cement and lime admixture on the index and engineering properties (compaction and unconfined strength) of tropical peat soils are presented. The ordinary Portland cement and hydrated lime were used. The amounts cement and lime added to the peat soil sample, as a percentage of the dry soil mass, were in the range of $5-15 \%$ and $5-25 \%$, respectively.

\section{TEST PROGRAMS AND SOIL SAMPLES}

A series of tests is conducted in order to examine the effect of cement and lime admixture on the index and mechanical properties of the peat. This includes the effect of curing time and cement and lime content on the Atterberg limit (liquid limit) of the peat, effect of cement and lime on the compaction characteristics (maximum dry density and optimum water content) on the peat and effect of cement and lime on the unconfined compressive strength of the peat as well as the influence of their organic content. The results obtained are presented below.

The ordinary Portland cement and hydrated lime were used as the chemical admixtures. The amounts cement and lime added to the peat soil sample, as a percentage of the dry soil mass, were in the range of 5$15 \%$ and $5-25 \%$, respectively.

For soil samples, tropical peat soils samples obtained from several locations in Malaysia, namely at Banting, Bukit Changgang and Dengkil, Selangor, were used in this study. The soil samples were obtained at a depth of $0.5 \mathrm{~m}$ to $1.0 \mathrm{~m}$ below the ground surface. The samples represent peat with organic content in the range of 75 to $94 \%$, natural water content 140 to $400 \%$ and liquid limit of 140 to $300 \%$. These soils have typically low specific gravity, in the range of 1.34 to 1.70 . According to Van Post scale (Landva et al. ${ }^{[13]}$ ), these soils are classified into the $\mathrm{H} 4$ to $\mathrm{H} 7$ group, namely hemic to sapric peat.

\section{RESULTS AND DISCUSSION}

\section{Cement admixture:}

Effect on liquid limit: Figure 4 shows the effect of cement on the liquid limit of the peat soil sample after a 1-day curing period. As shown the addition of cement decreases the soils liquid limit. The results also show that the decrease in liquid is more pronounced for soils with lower organic content and higher amount of mixing water.

The chemical reaction between additives such cement and soils are also known as time dependent. Figure 5 shows plots of liquid limit with curing time in days. As shown, the liquid limit of the soil-cement mixed decrease with increased in the curing duration. However, it was not possible to conduct any more liquid limit test after 7-days curing as the soil samples have become too hard. Figure 5 also shows the effect of mixing water on the liquid limit of the soil-cement mixed. Mixing water of 50 and $100 \%$ were examined in this study. As shown, for a particular soil-cement mixed, there is a bigger reduction in liquid limit when more water is made available for the chemical reaction to take place.

Effect on compaction characteristics: A series of test is conducted to study the effect of cement on the compaction characteristics of peat soil. These samples were compacted in accordance to the standard proctor test whereby the samples were compacted in three layers with a $2.5 \mathrm{~kg}$ rammer that delivers 27 blows to each layer. The results obtained are shown in Fig. 6.

As shown, the addition of cement has an influence in reducing the optimum water content and increasing the maximum dry unit weight of the peat soil.

Effect on unconfined compressive strength: Studies are carried out to examine the effect of cement on the unconfined compressive strength of the peat soil samples, namely to examine the effect of cement content and curing period, as well as the influence of organic content on the unconfined compressive strength of the peat soil samples. The samples were prepared by compaction with the modified proctor with mixing water content of $35 \%$. Figure 7 shows the plot of unconfined compressive strength with cement content, while Fig. 8 shows the influence of curing period on the unconfined compressive strength of the soil sample.

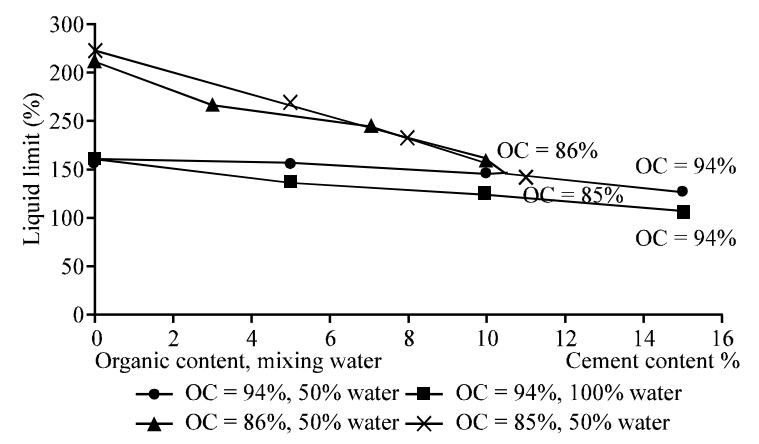

Fig. 4: Effect of cement on the liquid limit of peat soils

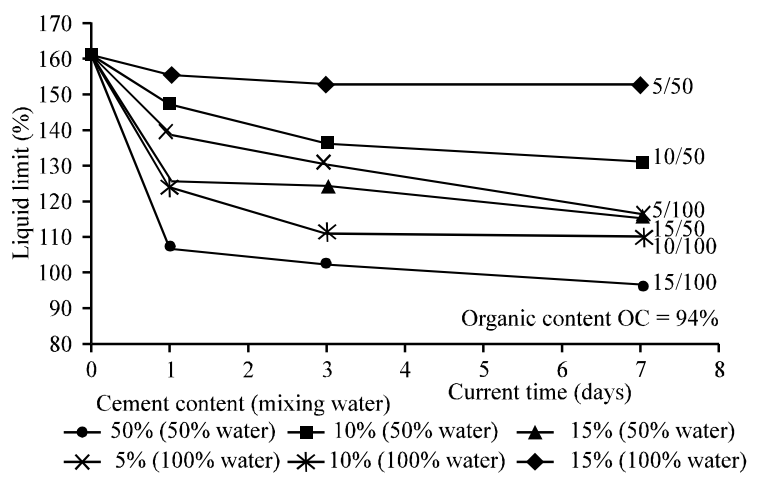

Fig. 5: Effect of curing time on the soil-cement mixed 


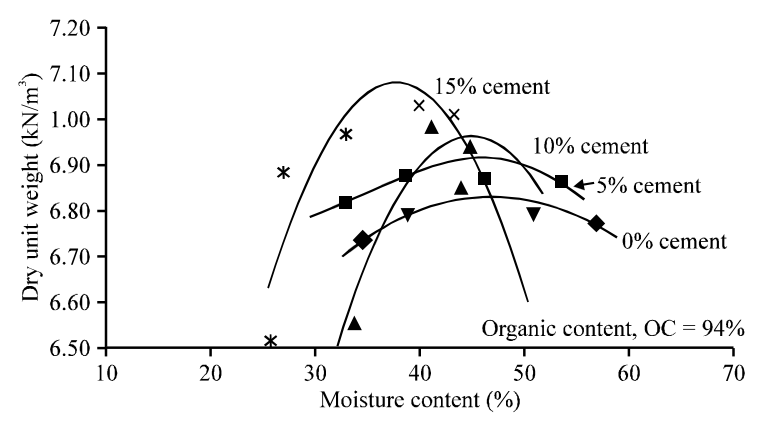

Fig. 6: Effect of cement on compaction characteristics of soil

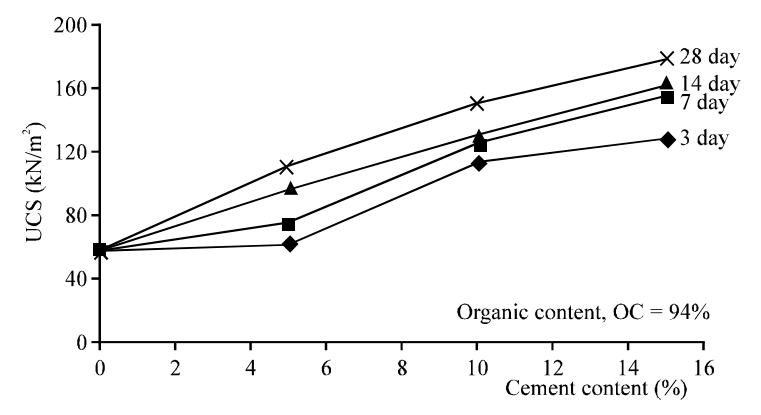

Fig. 7: Effect of cement on the unconfined compressive strength of peat

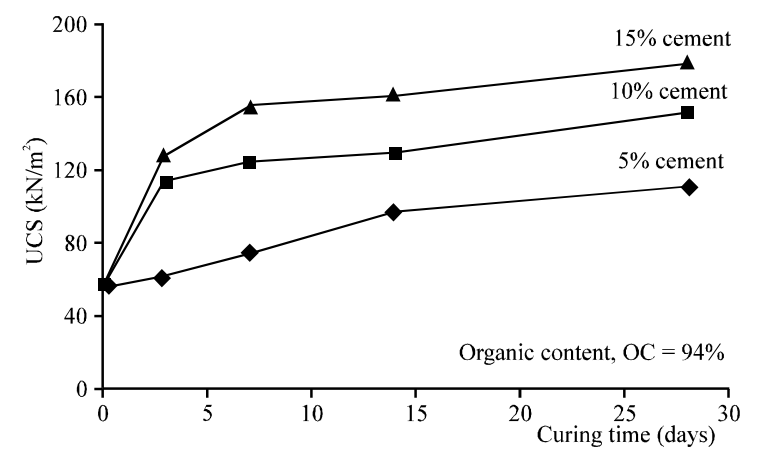

Fig. 8: Effect of curing period on the unconfined compressive strength of peat

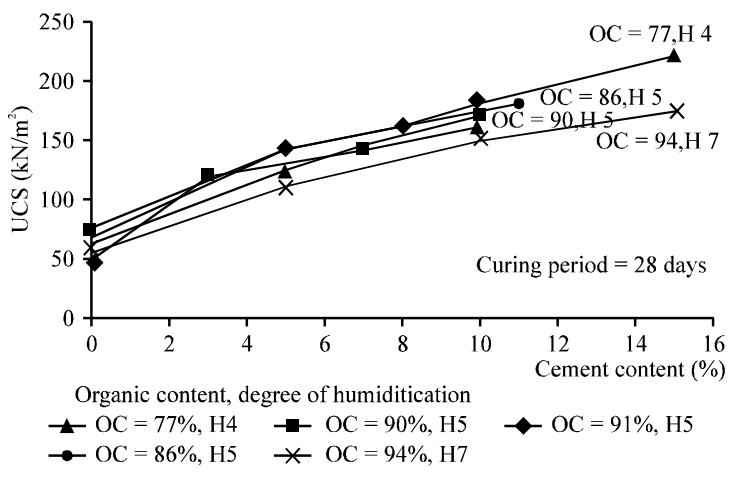

Fig. 9: Effect of organic content on the unconfined compressive strength of peat soils

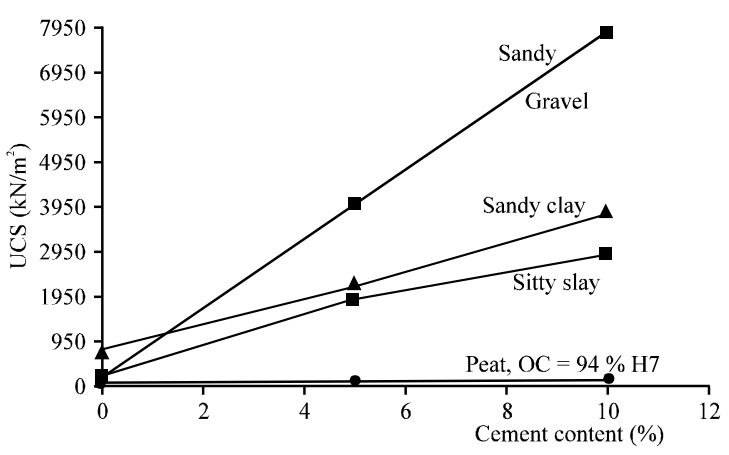

Fig. 10: Effect of cement on the unconfined compressive strength (28-days strength) of various soils

As shown increasing the cement content increases the unconfined compressive of the soil samples. Similarly higher strength is obtained from samples that have been cured for 28 days compared with the 3, 7, 14-days cured samples. It's of interest to note that in the case of cement stabilized clay, Bergado ${ }^{[14]}$ found that pozzolanic reaction can continue for months or even years after mixing, resulting in the increase in strength of cement stabilized clay with the increase in curing time.

Figure 9 shows the effect of organic content on the unconfined compressive strength of the peat soils. In general the compressive strength increase decrease with increase in the peat organic content. The results also show the compressive strength increase decrease with increase in peat degree of Humification (H). A similar finding was obtained by Huttunen et al. ${ }^{[15]}$. They reported the unconfined compressive strength of peat with different degree of humification and found that the strength increases with increasing dosage of cement and decreases as the humification increases.

Figure 10 shows the comparison of the effect of cement between organic (peat) and inorganic soils (sandy gravel, sandy clay and silty clay). In general the trend of behavior is similar. The addition of cement increases the unconfined compressive strength of the soil samples. However in case of organic soil (peat), although the strength of the treated soil is still low compared with the inorganic soils, but the addition of about $10 \%$ cement will cause almost a $250 \%$ increase in the unconfined compressive strength of the untreated (peat) soil after 28 days, i.e., 60 to $150 \mathrm{kN} / \mathrm{m}^{2}$ for the case of peat with organic content of $94 \%$ and degree of humification $(\mathrm{H})$ of 7 .

\section{Lime admixture:}

Effect on liquid limit: Figure 11 shows the effect of lime on the liquid limit of the peat soil sample after a 1day curing period. As shown the addition of lime decreases the soils liquid limit. The results also show that the decrease in liquid is more pronounced for soils with lower organic content. 


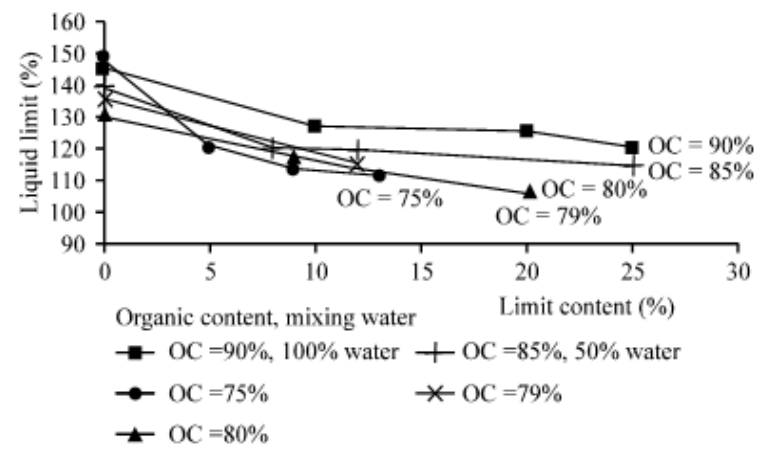

Fig. 11: Effect of lime on the liquid limit of peat soils

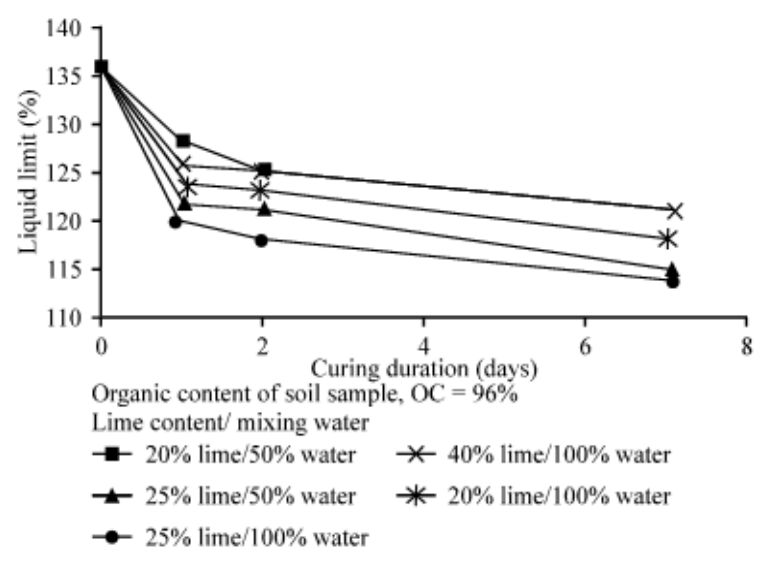

Fig. 12: Effect of curing time on the soil-lime mixed

A similar trend of behavior has been observed in the case of clay stabilized with lime ${ }^{[16]}$. The clay liquid limit was found to decrease with increase in lime content and so is the plasticity index thus making the soil more workable.

The chemical reaction between additives such lime and soils are also known as time dependent. Figure 12 shows plots of liquid limit with curing time in days. As shown the liquid limit of the soil-lime mixed decrease with increased in the curing duration. However, it was not possible to conduct any more liquid limit test after 7-days curing as the soil samples have become too hard. Figure 12 also shows the effect of mixing water on the liquid limit of the soil-lime mixed. Mixing water of 50 and $100 \%$ were examined in this study. As shown, for a particular peat soil lime mixed, there is a bigger reduction in liquid limit when more water is made available for the chemical reaction to take place.

Effect on compaction characteristics: A series of test is conducted to study the effect of lime on the compaction characteristics of peat soil. These samples were compacted in accordance to the modified proctor test whereby the samples were compacted in five layers with a $4.5 \mathrm{~kg}$ rammer that delivers 27 blows to each layer. The results obtained are shown in Fig. 13.

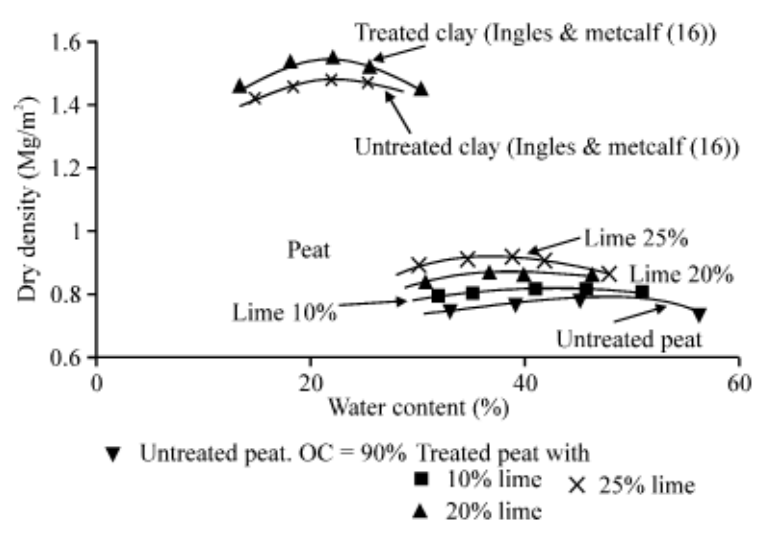

Fig. 13: Effect of lime on compaction characteristics of soil

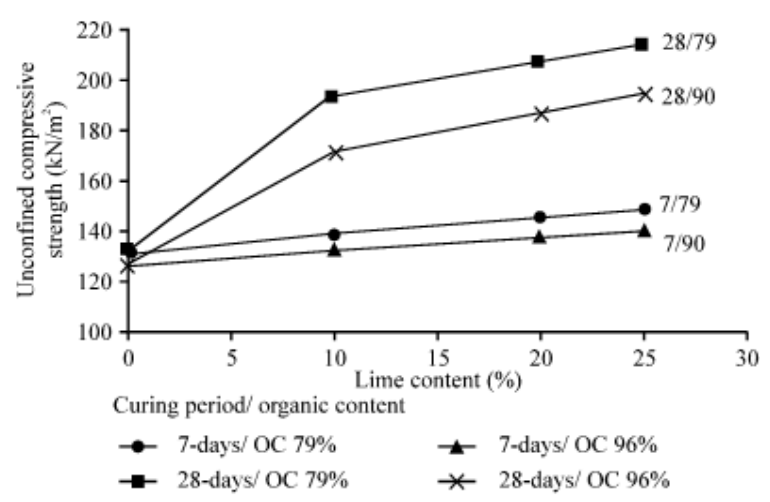

Fig. 14: Effect of lime on the unconfined compressive strength of peat

As shown, the addition of lime has an influence in reducing the optimum water content and increasing the maximum dry unit weight or dry density of the peat soil. A similar trend of behavior has also been observed in cases of lime treated clay (Ingles and Metcalf ${ }^{[16]}$ ).

Effect on unconfined compressive strength : Studies are carried out to examine the effect of lime on the unconfined compressive strength of the peat soil samples, namely to examine the effect of lime content and curing period, as well as the influence of organic content on the unconfined compressive strength of the soil samples. The samples were prepared by compaction with the modified proctor with mixing water content of $35 \%$. Figure 14 shows the plot of unconfined compressive strength with lime content, while Fig. 15 shows the influence of curing period on the unconfined compressive strength of the soil sample. As shown increasing the lime content increases the unconfined compressive of the soil samples. Similarly higher strength is obtained from samples that have been cured for 28 days compared with the 7-days cured samples. The plots also show that the higher strength gain is obtained with sample of the lower organic content. 


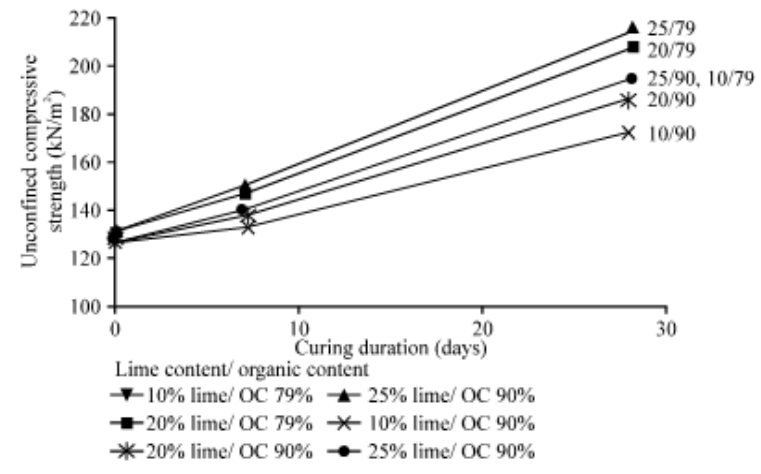

Fig. 15: Effect of curing period on the unconfined compressive strength of peat.

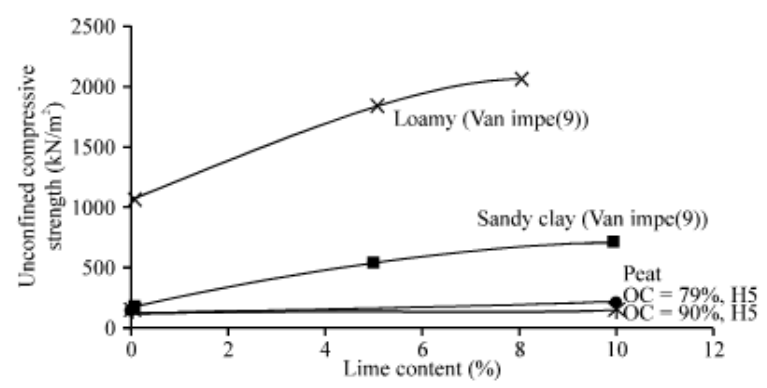

Fig. 16: Effect of lime on the unconfined compressive strength (28-days strength) of various soils

Figure 16 shows a comparison of the effect of lime between organic (peat) and inorganic soil. In general the trend of behavior is similar. The addition of lime increases the unconfined compressive strength of the soil samples. However in case of organic (peat) soil, although the strength of the treated soil is still low compared with the inorganic soils, but the addition of $10 \%$ lime will cause a 130 to $150 \%$ increase in the unconfined compressive strength of the untreated (peat) soil, i.e. From about 130 to 170 and $190 \mathrm{kN} / \mathrm{m}^{2}$ for peat soil with organic content of 79 and $90 \%$ respectively, after a curing period of 28 days. Both soils were with a degree of humification, $(\mathrm{H})$, of 5 .

It is also of interest to note when comparing the performance of cement and lime, it appears that cement is more effective in term of percentage of strength increase in improving the unconfined compressive strength of the tropical peat soils compared with the lime.

\section{CONCLUSION}

From the results of this study it can be concluded that the addition of the chemical admixture, cement and lime, can improve the engineering properties of tropical peat soils.

The soil liquid limit is found to decrease with an increase in the cement and lime content.
The soil maximum dry density is found to increase while the optimum water content is found to decrease with an increase in the cement and lime content.

The unconfined compressive strength of the soil is found to increase significantly with increase in cement and lime content, especially after a long curing period. However it is also found that higher organic content and degree of humification of the soil negate the positive effect of the cement and lime in altering (improving) the mechanical properties of the soil.

When comparing the performance of the cement and lime as a chemical admixture for tropical peat soil, the ordinary Portland cement appears to perform better (in term of percentage of strength increase) than the hydrated lime.

\section{REFERENCES}

1. Jarrett, P.M., 1995. Geoguide 6. Site investigation for organic soils and peat. JKR Document 207090341-95. Public Works Department Malaysia. Malaysia.

2. Hartlen, J. and J. Wolski, 1996. Embankments on organic soils. Elsevier.

3. Huat, B.B.K., 2004. Organic and peat soil engineering. University Putra Malaysia Press. Malaysia: Serdang.

4. Lam, S.K., 1989. Quaternary geology of Sibu town area, Sarawak, Malaysia. Geological Survey Malaysia. pp: 11-23.

5. Chen, S.P., S.K. Lam. and Y.K. Tan, 1989. Geology of urban planning and development in Sarawak, Seminar on urban geology for planners and decision makers in developing the urban environment. Geological Survey of Malaysia. Sarawak: Kuching.

6. Edil, T.B., 2003. Recent advances in Geotechnical characterization and construction over peat and organic soils. Proceedings 2nd International Conference on Advances in Soft Soil Engineering and Technology. (Eds). Huat et al. Malaysia: Putrajaya, pp: 3-25.

7. Janz, M. and S.E. Johansson, 2002. The function of different binding agents in deep stabilization. Swedish Deep Stabilization Research Center, Linkoping: SGI. 9.

8. Lancaster-Jones, P.F.F., E. McKeand and F.G. Bell., 1978. Ground treatment, Foundation engineering in difficult ground. London, Boston: Newnes-Butterworth.

9. Van Impe, W.F., 1989. Soil improvement techniques and their evolution. Balkema.

10. Little, D.N., 1995. Stabilization of pavement sub grades and base courses with lime. Dubuque, Iowa: Kendall/Hunt Publishing Company.

11. Ahnberg, H., C. Ljungkratnz and L. Holmqvist, 1995. Deep stabilization of different types of soft soils. Proceedings 11th ECSMFE, Copenhagen, 7:167-172. 
12. Arman, A. and G.A. Munfakh, 1972. Lime stabilization of organic soils. National Academy of Science. Highway Research. USA, PP: 381.

13. Landva, A.O., P.E Pheeney and D.E. Mersereau, 1983. Undisturbed sampling of peat. Testing of Peats and Organic Soils, ASTM STP 820. (Ed) Jarrett, pp: 141-156.

14. Bergado, D.T., 1996. Soil compaction and soil stabilization by admixtures. Proceeding of the seminar on ground improvement application to Indonesian soft soils. Indonesia: Jakarta, pp: 23-26.
15. Huttunen, E., K. Kujala and H. Vesa, 1996. Assessment of the quality of stabilized peat and clay. Symposium Grouting and Deep Mixing. Leiden: Balkema, pp: 607-612.

16. Ingles, O.G. and J.B. Metcalf, 1972. Soil stabilization principles and practice. John Wiley. New York. 